\title{
Incidence of Leaf Spot Disease Caused by Cercosporidium personatum in Resistant, Susceptible and Hybridized Population of Groundnut Cultivars
}

\author{
M. C. Kottayi ${ }^{1,2}$, D. D. Saoji ${ }^{1}$, S. E. Pawar ${ }^{3}$ \& A. D. Choudhary ${ }^{1}$ \\ ${ }^{1}$ Post Graduate Teaching Department of Botany, RTM Nagpur University, Nagpur, India \\ ${ }^{2}$ Division of Life Science, Navrachana University, Vadodara, India \\ ${ }^{3}$ Department of Atomic Energy, Board of Research in Nuclear Science, Mumbai, India \\ Correspondence: M. C. Kottayi, Division of Life Science, Navrachana University, Vasna Bhayli Road, Vadodara, \\ 391410, India. E-mail: kottayimonisha@gmail.com
}

Received: June 11, 2018

Accepted: July 16, 2018

Online Published: September 15, 2018

doi:10.5539/jas.v10n10p513

URL: https://doi.org/10.5539/jas.v10n10p513

The research was financed by Department of Atomic Energy, Board of Research in Nuclear Sciences, Mumbai, India.

\begin{abstract}
The disease incidence of Cercosporidium personatum in field was analysed in the hybridized population derived from the resistant mutant lines of the cultivar ICGV-87304 and TAG-24 \& TG-26. Reciprocal crosses were performed using the same parents. The comparison of disease incidence in hybridized population was made with resistant cultivar Girnar-1. Susceptible parents TAG-24 and TG-26 showed disease incidence of 14.08 and $16.40 \%$, respectively while Girnar-1 and the resistant mutant parents showed percentage infection ranging from $0.06-0.96 \%$. The plants raised from the hybridized population showed the percent infection ranging from 0.01 to $0.02 \%$.
\end{abstract}

Keywords: groundnut, Cercosporidium personatum, susceptible, pathogen

\section{Introduction}

Groundnut, Arachis hypogaea L. is a major oilseed crop of India, accounting for about $27 \%$ of global area and has a contribution of $19 \%$ to world groundnut production (Dwivedi \& Crouch, 2003). It is used for its oil as well as for food. It is an important cash crop of our country with 92 per cent fat, 46 per cent proteins, 24.2 per cent soluble carbohydrates, 8.4 per cent fiber and 5.8 per cent ash (Sheshadri, 1962). Early leaf spots are caused by Cercospora arachidicola Hori and late leaf spots are caused by Cercosporidium personatum (Berk.\&Curt.). These are among the most important diseases of groundnut (Subrahmanyam et al., 1982; Subrahmanyam \& Smith, 1989). The spots are first seen on the upper surface of lower leaves as small necrotic spots. These eventually enlarge and become light to dark brown or black circular spots, ranging from 1 to $10 \mathrm{~mm}$ in diameter. Gradually these spots coalesce and cause defoliation. Early leaf spots are characteristically brown to reddish brown in color with a yellow halo. The early leaf spot spores are formed on the upper leaf surface with a raised surface, and the lower leaf surface is usually smooth. Late leaf spots are seen as dark brown to black spots, usually without a yellow halo. The spores are formed on the lower surface with a rough appearance. The upper leaf surface is smooth (Tshilenge et al., 2010). These foliar diseases cause huge losses up to $25-43 \%$ as the photosynthetic process is disrupted. The pods thus produced are lesser and inferior in quality (Waliyar et al., 2000).

It is thus, very important to make attempts to transfer the resistant trait to the susceptible cultivars which are otherwise popular. The present paper deals with assessment of the selected cultivars in field and transfer of the resistant character from Mutant 10, 16, 22, 25, 26 and 29 (derived from ICGV-87304) to TAG-24 and TG-26 which are widely grown. 


\section{Material and Methods}

Seeds of two widely grown cultivars of $A$. hypogaea, TAG 24 and TG 26, developed by BARC were procured from Panjabrao Krishi Vidyapeeth, Akola, as a pure genetic stock. These two cultivars were susceptible to late leaf spot disease. The cultivar Girnar-1 was also procured and used as a resistant check. In addition, five mutant lines derived from ICGV-7304, developed at the Department of Botany, Nagpur University, Nagpur (Kale, 1998) were used for the hybridization experiments. All the five lines were resistant to late leaf spot disease (Table 1).

Table 1. Resistance status of different groundnut cultivars

\begin{tabular}{lll}
\hline \multirow{2}{*}{ Cultivars } & \multicolumn{2}{c}{ Status of resistance } \\
\cline { 2 - 3 } & Early leaf spot (Cercospora arachidicola) & Late leaf spot (Cercosporidium personatum) \\
\hline Girnar-1 & Resistant & Resistant \\
Mutant 10 & Resistant & Resistant \\
Mutant 16 & Resistant & Resistant \\
Mutant 22 & Resistant & Resistant \\
Mutant 25 & Resistant & Resistant \\
Mutant 26 & Resistant & Resistant \\
Mutant 29 & Resistant & Resistant \\
TAG 24 & Susceptible & Susceptible \\
TG 26 & Susceptible & Susceptible \\
\hline
\end{tabular}

The seeds of all plants selected above were sown in the experimental field of Department of Botany, Nagpur University, Nagpur, in plots of $10 \times 10$ size in the kharif season. Healthy plants (selected on the basis of percentage infection (calculated by measuring the diameter of the leaf spots in the infected area versus the total leaf area) and yield as compared to susceptible cultivars) from each cultivar in the population were selected for performing the crosses. The plants showed flowering after 34 days of germination. The anthers were emasculated on the previous day using sterile forceps from the female parent and these flowers were bagged. This was done to prevent any self pollination. The time of anthesis was found to be $6.50 \mathrm{AM}$. Post anthesis, the pollen grains from the male parent were carefully removed and dusted on the stigma of the female parent. The crossed flowers were bagged and labelled. The bagging was removed after formation of pegs.

In this investigation, Mutants 10, 16, 22, 25, 26 and 29 were crossed with TAG-24 and TG-26 (Table 2). Reciprocal crosses were also performed using the same parents. For identification of the hybridized flowers, they were tied with a thin nichrome wire. The hybridization process was performed up to 60 days of germination as the flowers failed to form pegs after this period. The total number of pegs, pods and seeds formed from the flowers which were used in hybridization experiment were calculated as a measure of successful hybridization. The population was termed the F1 population and the seeds of the F2 and F3 population raised form the F1 were also screened for disease resistance.

The F1 seeds were collected from the pods which were obtained from the pegs tied with nichrome wire. The F1 plants were screened for incidence of disease and percentage of infected area per leaflet in the field (Table 3). The seeds from F1 plants showing minimum amount of infection as compared to the susceptible cultivars were selected and F2 population was raised.These F2 plants were screened for resistance and other desirable characters.

\section{Results and Discussions}

The seeds of the selected cultivars were grown in the experimental field and monitored carefully for germination. The hybridization experiments were carried out between the resistant and susceptible cultivars and the plants were screened for the appearance of pegs from the hybridized flowers and for pod and seed setting (Table 2). The F1 plants and the subsequent F2 and F3 generations were assessed for incidence to Cercosporidium personatum on the basis of percentage of infected area per leaflet in the field grown plants. 
Table 2. Data on the number of pegs and pods formed in the crosses performed between cultivars, TAG-24 and TG-26, susceptible to late leaf spot and Mutant 16, 26, 29, 10, 22 and 25, resistant to late leaf spot disease

\begin{tabular}{|c|c|c|c|c|}
\hline Crosses & $\begin{array}{l}\text { Number of } \\
\text { crosses performed }\end{array}$ & $\begin{array}{l}\text { Number of } \\
\text { pegs formed }\end{array}$ & $\begin{array}{l}\text { Number of } \\
\text { pods formed }\end{array}$ & $\begin{array}{l}\text { Number of } \\
\text { crossed seeds obtained }\end{array}$ \\
\hline TAG $24 \times$ Mutant 26 & 196 & 44 & 20 & 20 \\
\hline TAG $24 \times$ Mutant 16 & 190 & 60 & 21 & 19 \\
\hline TAG $24 \times$ Mutant 29 & 392 & 198 & 83 & 78 \\
\hline Mutant $16 \times$ TAG 24 & 158 & 57 & 20 & 25 \\
\hline Mutant $26 \times$ TAG 24 & 258 & 86 & 28 & 30 \\
\hline Mutant $29 \times$ TAG 24 & 211 & 55 & 19 & 27 \\
\hline Mutant $10 \times$ TG 26 & 103 & 29 & 25 & 34 \\
\hline Mutant $22 \times$ TG 26 & 165 & 63 & 15 & 13 \\
\hline Mutant $25 \times$ TG 26 & 54 & 19 & 12 & 18 \\
\hline TG $26 \times$ Mutant 22 & 220 & 54 & 25 & 23 \\
\hline TG $26 \times$ Mutant 25 & 35 & 07 & 05 & 06 \\
\hline TG $26 \times$ Mutant 10 & 172 & 66 & 20 & 21 \\
\hline
\end{tabular}

In F2 population of the crosses involving TAG-24, thirteen lines were selected, while in the cross involving TG-26, only two selections were made, while the rest of the crosses did not yield resistant plants. The selected plants, however did not show absolute resistance but disease incidence was lesser than the susceptible parents in these selections. The cross between TAG-24 and mutants, M16, 22, 26 and 29 yielded \% infection in the range of 0.01-0.02 while the cross between TG-26 and M22 showed \% infection of 0.01 (Table 3). In the resistant check Girnar-1, the disease incidence in terms of $\%$ infection was $0.17 \%$. Thus, in selections made in this investigation showed resistance better than the resistant check. These results were also correlated with the accumulation of different biochemical markers like the phytoalexin-reveratrol and hydrolases, which accumulated in higher content in the resistant cultivars (data not presented). Thus, these results in terms of appearance of leaf spot disease indicated that all the fifteen selections made in the hybridized population were resistant to Cercosporidium personatum. 
Table 3. Data of percentage infection and yield of different lines derived from crosses between resistant cultivars and resistant mutants selected in F2

\begin{tabular}{|c|c|c|c|c|c|}
\hline Cross & $\begin{array}{l}\text { Lines resistant } \\
\text { to late leaf } \\
\text { spot disease }\end{array}$ & Plant type & $\begin{array}{l}\text { Percentage } \\
\text { of infected } \\
\text { area/leaflet }\end{array}$ & $\begin{array}{l}\text { Number of } \\
\text { pods/plant }\end{array}$ & Seed with plant \\
\hline \multirow[t]{5}{*}{ TAG $24 \times$ M26 } & $\mathrm{CA} / 2 / 10$ & Bunch & 0.01 & 05 & 2.32 \\
\hline & $\mathrm{CA} / 2 / 12$ & Bunch & 0.02 & 08 & 3.54 \\
\hline & $\mathrm{CA} / 3 / 2$ & Bunch & 0.02 & 11 & 4.20 \\
\hline & $\mathrm{CA} / 3 / 10$ & Bunch & 0.02 & 05 & 2.10 \\
\hline & $\mathrm{CA} / 6 / 7$ & Bunch & 0.01 & 05 & 3.86 \\
\hline \multirow[t]{7}{*}{ TAG-24 × M16 } & $\mathrm{CB} / 4 / 5$ & Bunch & 0.01 & 04 & 3.17 \\
\hline & $\mathrm{CB} / 6 / 6$ & Bunch & 0.02 & 05 & 2.63 \\
\hline & $\mathrm{CB} / 71$ & Bunch & 0.02 & 05 & 2.48 \\
\hline & $\mathrm{CB} / 8 / 2$ & Bunch & 0.02 & 12 & 4.36 \\
\hline & $\mathrm{CB} / 11 / 1$ & Bunch & 0.02 & 12 & 4.27 \\
\hline & $\mathrm{CB} 11 / / 5$ & Bunch & 0.02 & 08 & 3.42 \\
\hline & $\mathrm{CB} / 12 / 1$ & Bunch & 0.01 & 15 & 4.44 \\
\hline TAG $24 \times$ M 29 & $\mathrm{CC} / 14 / 3$ & Bunch & 0.01 & 06 & 3.39 \\
\hline \multirow[t]{2}{*}{ TG $26 \times \mathrm{M} 22$} & $\mathrm{CD} / 2 / 4$ & Bunch & 0.01 & 08 & 3.34 \\
\hline & $\mathrm{CD} / 17 / 2$ & Bunch & 0.01 & 09 & 3.53 \\
\hline \multicolumn{6}{|l|}{ Parents } \\
\hline \multicolumn{2}{|l|}{ TAG 24} & Bunch & 14.08 & 10 & 4.12 \\
\hline \multicolumn{2}{|l|}{ M26 } & Bunch & 0.96 & 08 & 3.28 \\
\hline \multicolumn{2}{|l|}{ M16 } & Bunch & 0.14 & 11 & 4.46 \\
\hline \multicolumn{2}{|l|}{ M29 } & Semi-erect & 0.25 & 10 & 4.18 \\
\hline \multicolumn{2}{|l|}{ TG26 } & Semi-erect & 16.40 & 17 & 5.43 \\
\hline \multicolumn{2}{|l|}{ M 22} & Bunch & 0.06 & 2 & 1.78 \\
\hline \multicolumn{2}{|c|}{ Girnar-1 (Used as resistant Check ) } & Bunch & 0.17 & 13 & 5.62 \\
\hline
\end{tabular}

Note. Rest of the crosses did not yield the resistant plants.

Bunch variety: The plant grows erect, possesses light-green foliage, produces pods in cluster at the base of the plant and has round, plump non-dormant seeds with light-rose testa. Semi-erect variety: Green to dark green leaves. It has 3-seeded (occasionally, 4-, 2-, or 1-seeded) pods, with slight to moderate ridges, slight reticulation, and with slight to moderate beaks and constrictions.

The transfer of resistant trait from related species to cultivated groundnut was successfully attempted by Smart (1978), and Gibbons (1980). They claimed that hybrids were resistant to early and late leaf spot. Similar investigations were made by many researchers in different crops (Alberschiem \& Valent, 1978; Vidyashekharan, 1997; Kale, 1998; Koche et al., 2015). However, this is the successful attempt to transfer the resistant trait from mutant lines to popular cultivar TAG-24 and TG-26.

\section{References}

Alberschiem, P., \& Valent, B. S. (1978). Host-pathogen interactions in plants. J Cell Biol, 78, 627-643.

Dwivedi, S. L., \& Crouch, J. H. (2003). Proceedings of a workshop for the Asian Development Bank supported project on molecular breeding of sorghum, groundnut and chickpea (pp. 28-43). ICRISAT, India.

Gibbons, R. W. (1980). Groundnut improvement research technology for the semi-arid tropics. Proceedings of the International Symposium on Development and Transfer of Technology for Rain-fed Agriculture and the SAT Farmer (pp. 27-37). ICRISAT, India.

Kale, M. C. (1998). Studies on induced defense responses in Arachis hypogaea L. (PhD thesis, Nagpur University, Nagpur, India).

Koche, D., Badere, R. S., Choudhary, A. D., \& Pawar, S. E. (2015). Assessment of Cercospora leaf spot (CLS) disease incidence in naturally grown population of seven mungbean cultivars.

Sheshadri, C. R. (1962). Groundnut (p. 274). Hyderabad, Andhra Pradesh, India: Indian Central Oilseeds Committee. 
Smart J. (1978). Makulu red-A 'green revolution' groundnut variety? Euphytica, 27, 605-608. https://doi.org/10.1007/BF00043190

Subrahmanyam, P., McDonald, D., Gibbons, R. W., Nigam, S. N., \& Nevill, D. J. (1982). Resistance to rust and late leafspot diseases in some genotypes of Arachis hypogaea. Peanut Science, 9(1), 6-10. https://doi.org/10.3146/i0095-3679-9-12

Subrahmanyam, P., \& Smith, D. H. (1989). Influence of temperature, leaf wetness period, leaf maturity, and host genotype on web blotch of peanut. Oleagineux, 44, 27-31.

Tshilenge, L. (2010). Pathosystem Groundnut (Arachis hypogaea L.), Cercospora spp. and Environment in DR-Congo: Overtime Interrelations. In K. K. C. Nkongolo (Ed.), Contribution to food security and malnutrition in DR-Congo (195-221). Laurentian Press.

Vidhyasekaran, P. (1997). Fungal pathogenesis in Plants and crops: Molecular biology and Host defense mechanism. Marcel Dekker, New York.

Waliyar, F., Adomou, M., \& Traore, A. (2000). Rational use of fungicide applications to maximize peanut yield under foliar disease pressure in West Africa. Plant Disease, 84, 120-12. https://doi.org/10.1094/ PDIS.2000.84.11.1203

\section{Copyrights}

Copyright for this article is retained by the author (s), with first publication rights granted to the journal.

This is an open-access article distributed under the terms and conditions of the Creative Commons Attribution license (http://creativecommons.org/licenses/by/4.0/). 